\title{
The iconic Hector Pieterson photo and the power of adaptations Ewald Mengel
}

\begin{abstract}
The iconic Hector Pieterson photo and the power of adaptations
In South Africa, the iconic Hector Pieterson photo is the starting point for many artists to deal with their own personal trauma and the communal trauma of their nation. The iconicity of this photo has sparked many different adaptations in various fields of art. Considering that we are talking about a traumatized country, Freud's concept of "repetition compulsion" seems to be one explanation for this phenomenon. However, art is only seldom a mere product of traumatization. Quayson's concept of "symbolization compulsions" comes closer to explaining the phenomenon of repetition in the arts, because it leaves the artists more freedom of expression and does not suggest that art is the result of illness, while still implying 'compulsion' and 'obsession' in the act of creation. I want to suggest that 'repetition' in the arts in the South African context is not so much a sign of confinement and restriction, but that the many adaptations of the unique historical incident should rather be understood as attempts of 'working through' collective trauma, making sense of history, and contributing to the country's healing. Keywords: Hector Pieterson, repetition compulsion, symbolization compulsions, adaptation, trauma, art.
\end{abstract}

During the symposium 'What Does It Mean Living Together in the Aftermath of Historical Trauma', organized by Pumla Gobodo-Madikizela at the University of the Free State in Bloemfontain, South Africa from 24 to 26 March 2014, a workshop was held for students in the gallery of the university library, which I was invited to attend. Its subject was Gerrit Hattingh's fine art photograph Before and After Hector. When the students were encouraged to voice their opinions about it, most of them seemed to like it. Some of them expressed their uneasiness about it, while others felt that there was 'something missing' in this photograph. I, too, felt the same, although at the time I was unable to put it into exact words. Having dealt with adaptations before (Mengel), I knew for sure that adaptations by definition have to change things, to leave things out, or to add things, because otherwise they would be copies and not adaptations at all (on adaptation theory see Hutcheon). It was only later that I remembered the terminology of C. S. Peirce, the founder of semiology, and it became clear to me that Peirce's distinction between three types of signs - 'icon', 'index', and 'symbol'-is helpful to analyze the phenomenon in question, and describe the 'missing link' in a more scholarly way.

According to Peirce (see Bergman and Paavola), the term 'icon' is a sign that bears some likeness or semblance to reality. An icon is a simplified visual representation of something else, for example, a program on your computer for which the icon serves as an easily recognizable button. A photograph would also be a good example for we assume that there is a reality behind it to which it bears a likeness. But the terms 'icon' and 'iconicity' also have a second meaning because originally they refer to the image of a saint.

The concepts 'index', 'indexicality', and 'indexical meaning' imply an actual reference, a concrete and real relation bound to a historical context: The Obama family introduce 'First Dog' Bo, a Portuguese water dog, to the press on 14 April 2009 on the lawn outside the White House in Washington (my example). The event here is historical and unique, and its veracity may be underpinned by referring to eyewitnesses, photographs, or video films.

In contrast to indexical meaning, referential meaning according to Peirce is less context-bound, more general, and lacks historical specificity and uniqueness: 'A dog runs on the lawn'. In this case, the meaning-generating reference is just to the animal species that is specified (dog), the way it moves (runs), and the locality (lawn).

The third type of sign that matters in this context is symbols. On a linguistic level, a symbol stands for some object or idea it represents. The English word 'dog' (Latin: canis, French: chien, German Hund), for example, designates a well-known domesticated animal with four legs that can bark. Linguistically, there is no 'actual', 'corporeal' relation or similarity between signifier and signified, but this relation is arbitrary. As literary symbols,

Ewald Mengel is Professor of English and American Literature and Culture at the Tomas Bata University in Zlín, Czech Republic. His current research interest is trauma in contemporary Anglo-African literature.

Email: mengel@utb.cz

(D) https://orcid.org/0000-0003-4667-701X

DOI: https://doi.org/10.17159/2309-9070/tvl.v.56i2.6134 
dogs may signify almost anything, depending on the context in which they are used. In the contemporary South African novel, for example, dogs occur quite frequently and have even become objects of scholarly analysis (Wylie and Barendse).

Sam Nzima's iconic Hector Pieterson photo from 1976, which was printed in the newspaper The World, literally went around the world and is known to all of us today. Circulated mainly by newspapers and television at first, the internet became an important multiplier from the 1990s onward. What we find on the internet nowadays is not just the 'one and only' iconic photo but a series of shots which show the group of the three young students from different perspectives and distances.

In the original photo we see a disorientated crowd of black people in the background, some of them looking in the direction of the group. A woman is seen on the left, also looking towards them. The limp body of Hector Pieterson, clad with short trousers and one gym shoe, is being carried by an older male student (Mbuyisa Makhubu), who is half crying, while a female student in school uniform (Hector's sister Antoinette Sithole) is walking by his side, wailing, the palm of her right hand thrown upwards in a gesture of lament (or is it to shield off bad luck?).

In a second photo the group has advanced, the crowd is no longer to be seen, and the woman in the background is now on the right side of the photo, no longer looking towards the children but in the direction of where the crowd was before and where there still seems to be trouble. Hector's head is thrown back even further, the mouth of the student carrying him again is wide open, half crying, and Hector's sister is still walking by his side, crying and holding the palm of her right hand upwards like in the first picture.

There are more photos to be found on the internet-it is an ideal platform for distributing them. The photographer Sam Nzima shot a series of six with a simple Pentax camera (Molosankwe; Pohlandt-McCormick) and smuggled the film through the police control in one of his socks. From there, it went to the offices of the newspaper The World, which dared to publish the photo on its front page.

The following cartoon by Zapiro, a rough version of which, chiselled into stone, is gracing the monument before the Hector Pieterson Museum in Orlando West, Soweto, and which obviously catches all those elements which make up the photo's material iconicity - the group of three; Hector's limp body; the half crying, open mouth of the older student; the crying sister with the palm of her right hand thrown upwards-represents a more modern version of the Hector Pieterson motif.

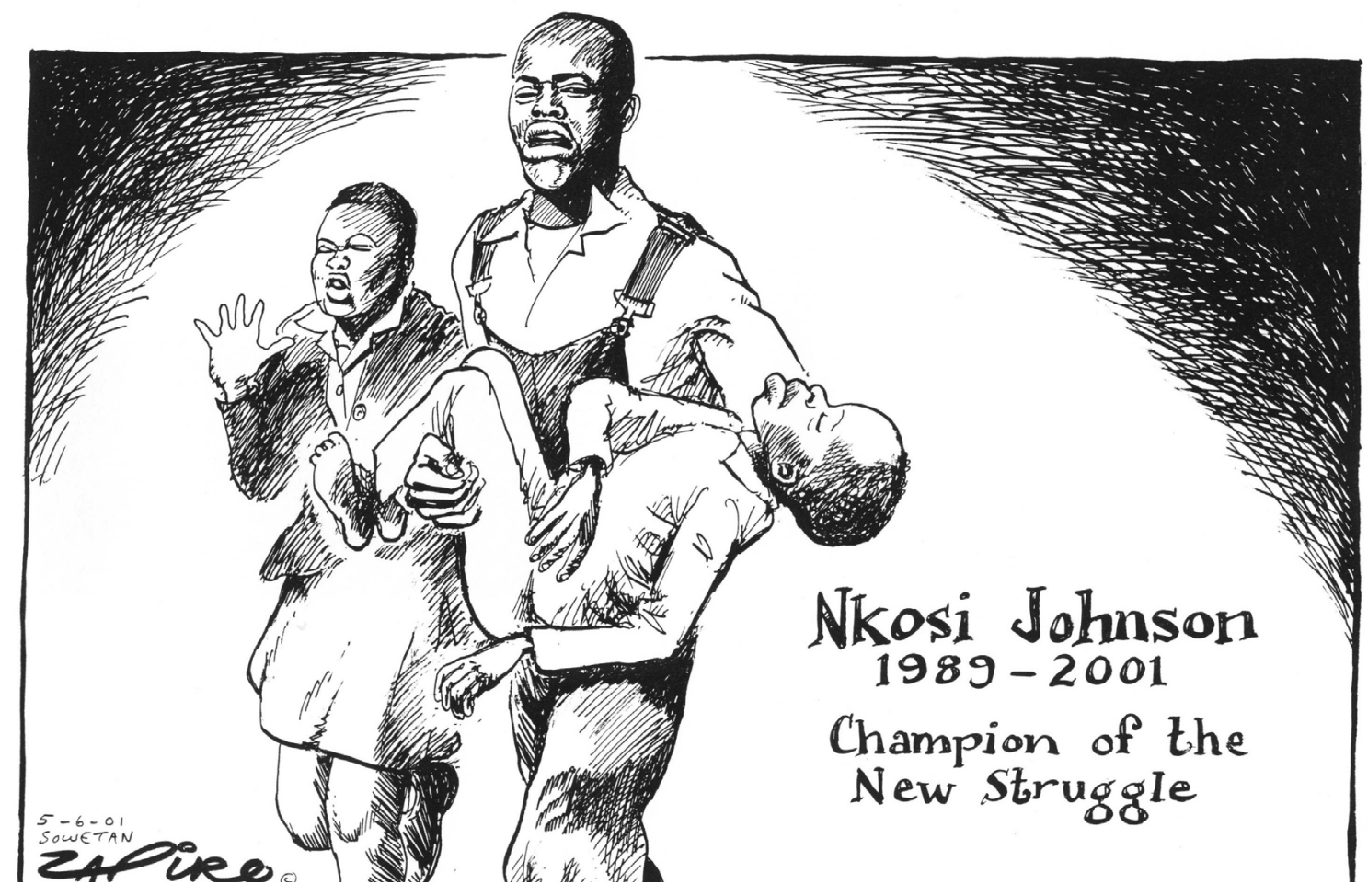

Figure 1: Zapiro Obituary cartoon: Nkosi Johnson (1989-2001). Originally published in Sowetan. Re-published with permission. 
It is interesting to note that there is-intentionally-no historical exactness in the Zapiro cartoon. While the shape of the older student's mouth and the position of the sister's hand are meticulously observed, the dying child here has bare feet and wears a pair of long trousers. Zapiro's drawing turns out to be an adaptation that does not aim at historical accuracy. The victim here is called Nkosi Johnson, who was born HIV positive in 1989 and became a celebrity in South Africa in the last decade of the $20^{\text {th }}$ century, fighting against the discrimination of children and adults known to have HIV/AIDS. Nelson Mandela referred to him as "an icon of the struggle for life" (BBC News). He died of AIDS in 2001.

Gerrit Hattingh's fine art photograph Before and After Hector, too, is obviously meant to allude to the iconic Hector Pieterson photo, whose constitutive elements are preserved: the group of three, the limp body of the child carried by a strong young man, the woman at his side, the palm of her right hand raised upwards. However, there are also a number of changes: the setting is no longer the township of Soweto but a beautiful natural scene on a sunlit day; there is no crowd of protesters in the background and the people in the photograph wear turn-of-the century clothes. Hattingh's adaptation is to remind us of the many black people $(15,000-20,000)$ who lost their lives in British concentration camps during the Anglo-Boer War 1899-1902.

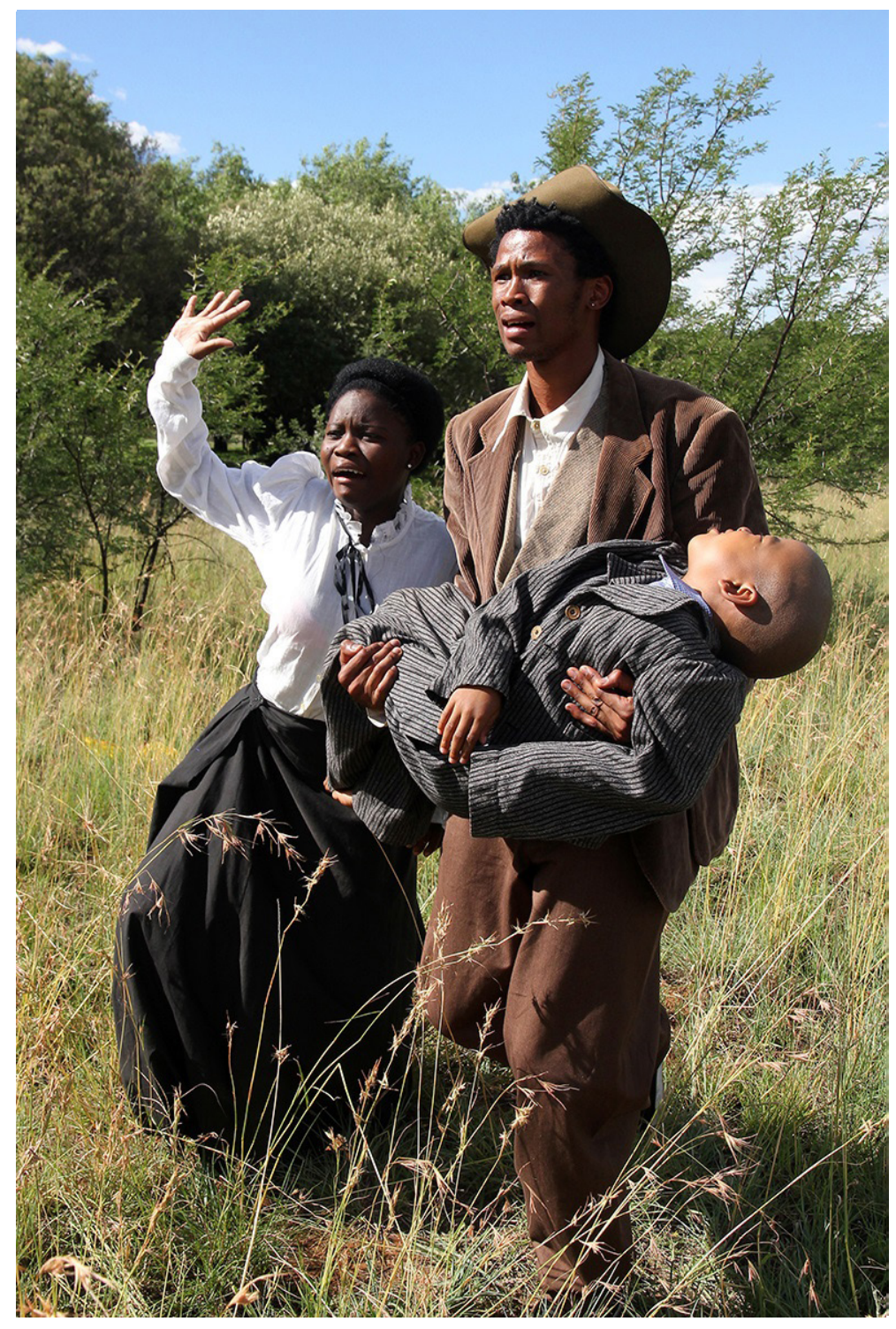

Figure 2: Gerrit Hattingh Before and after Hector. Published with permission. 
The reason for the boy's trouble seems to be related to this. There is no indication that he is shot, but what we know is that many people in the concentration camps suffered from malnutrition and died from various infectious diseases, some of them outside the camps after they were released (South African History Online). The man and the woman are obviously trying to get help for the young boy who seems to be in serious trouble. But are they still students? It would hardly make sense in this different historical context. They could be the brother and sister, or even the parents of this child.

One more example will suffice to illustrate how the iconicity of the Hector Pieterson photo can be adapted for different purposes.

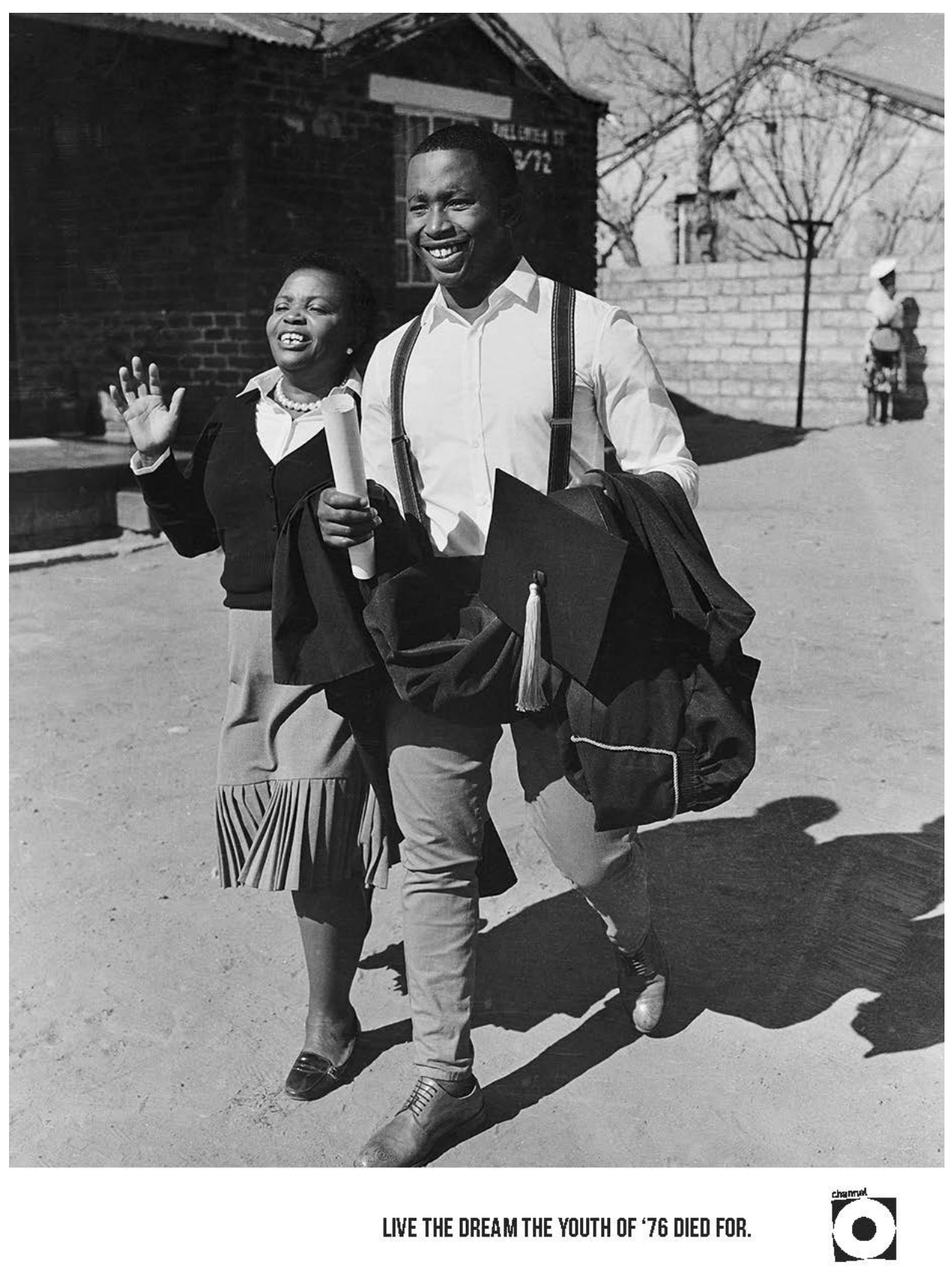

Figure 3: Picture by Nganga Dlanga of the Black River FC advertising agency. Republished with permission. 
In this picture, two broadly smiling college students are imitating the iconic Hector Pieterson situation. The body of Hector is replaced by a mortar board, a gown and a scroll. It seems that the students celebrate their graduation. The allusion to Hector Pieterson in this context, on the one hand, is to remind us for what the Soweto students in 1976 fought and died for, namely equality and freedom of education. On the other hand, one cannot avoid noticing the more sinister undertones of this picture (Davids and Mbele; Ferreira): Is that what they proudly carry already a corpse? Will their graduation really set them free, or will they be swallowed up by the army of unemployed academics, since South Africa's economy has once again hit a recession?

Hector Pieterson was shot by the apartheid police on 16 June 1976 in Orlando West, Soweto. The original, iconic Hector Pieterson photo by Sam Nzima 'freezes' the moment after this incident as a unique historical moment in time. It captures the attempt to save Hector's life, and shows the emotions of Antoinette and Mbuyisa that go along with it. This is its indexical meaning. The referential meaning of the picture is that the South African police did not hesitate to shoot at and kill school children. Hector was not the first and the only one-a few hundred people were killed on that day and the days after. Thus, the picture could become a symbol of the cruelty of the apartheid regime, and the suffering of the black population under their white oppressor.

Iconicity presupposes repetition, circulation, and multiplication. Adaptations are 'translations' (in the widest sense of the word) from a source context into a target context. They make use of the referential and symbolical meaning of an icon, while its indexical meaning has to be suppressed because it is an obstacle for the adaptation process. If one feels some loss looking at Gerrit Hattingh's 'retrospective' adaptation, this loss is created by the lack of indexicality which, however, is a necessary precondition for an adaptation to come about at all. The same applies to the students celebrating their graduation.

Since 1976, many adaptations of the iconic Hector Pieterson photo have been produced in different forms across the fine arts (Saayman-Hattingh) for different purposes. In the South African context, one is tempted to explain this phenomenon by referring to Sigmund Freud's idea of repetition compulsion. After all, we are dealing with a collective (communal, societal) trauma that seems to be haunting the South African nation (Tutu; Volkan).

Freud has turned repeatedly to the concept of repetition compulsion in his writings. He did this for the first time in an article of 1914, "Erinnern, Wiederholen und Durcharbeiten" (Remembering, Repeating, and Working-Through). He took it up again in "Jenseits des Lustprinzips" (Beyond the Pleasure Principle), where he emphasizes that the "patient cannot remember the whole of what is repressed in him, and what he cannot remember may be precisely the essential part of it $[\ldots]$ He is obliged to repeat the repressed material as a contemporary experience instead of, as the physician would prefer to see, remembering it" (288). This means that Freud's idea of repetition compulsion leaves no room for artistic creativity or freedom. The traumatic past is "unclaimed experience" (Caruth), unspeakable and unrepresentable, and according to Caruth, it will keep haunting the present.

With Ato Quayson's theory of "symbolization compulsions", we enter the realm of representation. Symbolic representation allows individual artistic creativity, but Quayson still clings to the idea that there is a compulsion of sorts that is triggered by communal trauma: "Symbolization compulsion is the drive towards an insistent metaphorical register even when this register does not help to develop the action, define character or spectacle, or create atmosphere. It seems to be symbolization for its own sake, but in fact is a sign of a latent problem" (82).

In the South African context, this latent problem is contemporary communal and societal trauma, and it seems that South African artists keep returning to the same situations, motifs, and character constellations that other artists have been dealing with before. This repetitiveness of South African arts may be seen in a negative light. Elleke Boehmer, for example, draws a rather bleak picture in her article "Permanent Risk: When Crisis Defines a Nation's Writing". But the fact that the arts keep returning to this communal trauma can also be interpreted positively. The many adaptations of the iconic Hector Pieterson photo, for example, may be understood as repeated attempts to come to terms with this trauma, to work through it, and to be able to live with it, even if it might not be overcome finally. Repetitions are necessary in this context. As such, they are an indication of strength in spite of the existing trauma, and the willingness to face the past, to work through it, and come to terms with past atrocities. Their common starting point is the iconicity of this photo, which shows Apartheid society and its problems through a magnifying lens. By repetitive variation, the adaptations create a web of meaning that relates the past to the present and brings seemingly unrelated events and persons into a surprising and meaningful relationship.

The parallels between the four totally different historical situations and events become clear: through the iconic power of the original Hector Pieterson photo, the suffering of black people under apartheid rule is prospec- 
tively related to the scourge of AIDS, the problem of education, and the inactivity of the ANC government in the present, and retrospectively to the many deaths of black people in concentration camps set up by British troops a hundred years earlier. The iconicity of the original Hector Pieterson photo empowers these 'flights of thought' and lends the later adaptations their meaning. It creates a net of semantic relationships that combines hitherto unrelated elements in a surprising way. At the center is black suffering, both in the time of colonialism and under the present political conditions. The intermedial adaptations of the iconic Hector Pieterson photo thus construct a new transmedial narrative that tries to make sense of South African history.

\section{Works Cited}

BBC News. "Profile: Mandela’s magic touch". 28 Aug. 2001. http://news.bbc.co.uk/2/hi/africa/1513244.stm. Accessed 3 Mar. 2019.

Bergman, Mats \& Sami Paavola, eds. The Commens Dictionary. Peirce's Terminology in His Own Words. 2003. http://www.commens. org/dictionary. Accessed 3 Mar. 2019.

Boehmer, Elleke. "Permanent Risk: When Crisis Defines a Nations Writing”. Trauma, Memory, and Narrative in South Africa: Essays. Eds. Ewald Mengel \& Michela Borzaga. Rodopi, 2012, pp. 28-46.

Caruth, Cathy. Unclaimed Experience: Trauma, Narrative, and History. Johns Hopkins U P, 1996.

Davids, Nashira \& Gabi Mbele. "Emotion high at rework of iconic picture". The Herald (South Africa). 17 Jun. 2015. https:// www.pressreader.com/south-africa/the-herald-south-africa/20150617/281535109621617. Accessed 8 Mar. 2019.

Ferreira, Thinus. "Channel O Youth Day ad stirs up a storm”. Channel 24. 17 Jun. 2015. https://www.channel24.co.za/TV/ News/Channel-O-Youth-Day-ad-stirs-up-a-storm-20150617. Accessed 8 Mar. 2019.

Freud, Sigmund. “Beyond the Pleasure Principle.” On Metapsychology. Ed. Angela Richards. Penguin, 1984, pp. 275-338.

Hutcheon, Linda. A Theory of Adaptation. Routledge, 2006.

Mengel, Ewald. On First Looking into Arden's Goethe: Adaptations and Translations of Classical German Plays for the Modern English Stage. Camden House, 1994.

Mengel, Ewald \& Michela Borzaga, eds. Trauma, Memory, and Narrative in the Contemporary South African Novel: Essays. Rodopi, 2012.

Molosankwe, Botho “Hector Pieterson pic ruined my life.” IOL. 12 Jun. 2013. http://www.iol.co.za/news/south-africa/ gauteng/hector-pieterson-pic-ruined-my-life-1.1531027\#.U0filV4ijwI. Accessed 3 Mar. 2019.

Pohlandt-McCormick, Helena. "Story of a Photograph-Sam Nzima". Gutenberg-e.org. http://www.gutenberg-e.org/ pohlandt-mccormick/pmh0la.html. Accessed 3 Mar. 2019.

Quayson, Ato. "Symbolization Compulsions." Calibrations: Reading for the Social. Ed. Ato Quayson. U of Minnesota P, 2003, pp. 76-98.

Saayman-Hattingh, Heidi. "Understanding Cultural Identity and Visual Communication in the Appropriation of Iconic Photojouralism.” The Sixth International DEFSA Conference Proceedings 2011, pp. 172-82. http://www.defsa.org.za/ papers/understanding-cultural. Accessed 22 Jun. 2019.

South African History Online. "Black Concentration Camps during the Anglo-Boer War 2, 1900-1902." http://www.sahistory. org.za/topic/black-concentration-camps-during-anglo-boer-war-2-1900-1902. Accessed 3 Mar. 2019.

Tutu, Desmond. Archbishop Tutu's Address to the First Gathering of the Truth and Reconciliation Commission. http:// www.justice.gov.za/trc/media/pr/1995/p951216a.htm. Accessed 3 March 2019.

Volkan, Vamik D. "The Next Chapter: Consequences of Societal Trauma." Memory, Narrative and Forgiveness: Perspectives on the Unfinished Journeys of the Past. Eds. Pumla Gobodo-Madikizela \& Chris van der Merwe. Cambridge Scholars, 2009, pp. 1-26.

Wylie, Dan \& Joan-Mari Barendse, eds. Dogs in Southern African Literatures. Van Schaik, 2018.

Zapiro. Obituary cartoon: Nkosi Johnson. https://www.zapiro.com/010605so. Accessed 3 Mar. 2019. 